Original Research

\title{
Family Experience in Dealing with Emergency Cardiovascular Disease
}

\section{Ratna Puji Priyanti1, Anja Hesnia Kholis1, Asri Asri2, Rifa'I Rifa'i1 and Supriliyah Praningsih1}

1STIKES Pemkab Jombang, Indonesia

${ }_{2}$ Faculty of Health Science, Muhammadiyah Surabaya University, Indonesia

\begin{abstract}
Background: The risk of cardiovascular disease has shifted. Cardiovascular disease initially only affected certain age groups but not with the current incidence of cardiovascular disease. This makes the community more susceptible to cardiovascular disease attacks. An attack of cardiovascular disease, in general, is only considered to be a cursory attack. The patients with high-risk factors must be supported by the ability of families to recognize and perform first aid in cardiovascular disease attacks. The purpose of this study was to understand the family's experience in dealing with emergency heart disease at home.
\end{abstract}

Method: This study used qualitative research with a case study approach; 2 participants with family members who face emergency heart disease were selected. The data collection used semi-structured interview techniques using an observation and field notes. The data analysis used Creswell's qualitative data analysis method. The results of the study found 4 themes related to the family experience in dealing with emergency heart disease at home.

Result: The themes were knowledge, past experience, values and beliefs.

Conclusion: The conclusion of the study is that the family experience when dealing with emergency heart disease is strongly influenced by the knowledge that forms a value and belief which then influences the attitudes involved in decision making.

\section{ARTICLE HISTORY}

Received: Dec 26, 2019

Accepted: Dec 31, 2019

\section{KEYWORDS}

family experience; emergency; cardiovascular disease

\section{CONTACT}

Ratna Puji Priyanti

$\triangle$ ns.ratnapuji@gmail.com

$\risingdotseq$ STIKES Pemkab Jombang, Indonesia

Cite this as: Priyanti, R. P, Kholis, A.H, Asri, A, Rifa'i, R \& Praningsih, S. (2019). Family Experience in Dealing with Emergency Cardiovascular Disease. Jurnal Ners, 14(3si), 205-208. doi:http://dx.doi.org/10.20473/jn.v14i3(si).17020

\section{INTRODUCTION}

Changes in lifestyle today have changed the epidemiology of disease. The epidemiological of disease is shifting from infectious disease to noncommunicable disease. One non-communicable disease is cardiovascular disease. Cardiovascular disease, especially infarctions and stroke, are the main killer in developing countries like Indonesia (Adiatmaja, 2004). In 1900, a person said to have a risk of developing cardiovascular disease was someone with high blood pressure or pregnant women, as well as someone who had a high cholesterol level(Dalen, Alpert, Goldberg, \& Weinstein, 2014; Wyatt et al., 2008). However, lately, lifestyle changes can be a risk factor for cardiovascular disease(Voss, Cullen, Schulte, \& Assmann, 2002). The mortality rate from cardiovascular disease in the world has reached 17.9 million per year; $31 \%$ of the total causes of death and $85 \%$ are caused by heart disease (WHO, 2016). The prevalence of coronary heart disease in Indonesia based on a doctor's diagnosis conducted by the 2013 Basic Health Research (Riskesdas) was 0.5\%, while based on a doctor's diagnosis or symptoms, it was 1.5\% (BALITBANGKES, 2014).

Today's cardiovascular disease does not only affect the elderly age group (Delima, Mihardja, \& Siswoyo, 2009). The risk of cardiovascular disease shifts makes more people susceptible to cardiovascular disease attacks. The attack of cardiovascular disease, in general, is only a fleeting attack. This attack can frighten the sufferers. The coping ability of the patients with high-risk factors must be supported by the ability of the family to 
recognize and perform first aid in the event of an attack of cardiovascular disease.

The role of the family in recognizing health problems is a part of them being able to make health decisions, to take care of their sick family members, to modify the environment and to utilize the existing health facilities (Friedman, Bowden, \& Jones, 2010). The family members must be aware that any changes in the behavior of patients with high-risk factors for cardiovascular disease can provide clues to the cardiovascular disease itself. In addition, attacks of cardiovascular disease require help from the family who are the people closest to the patient (Suastika, 2016). Therefore, family involvement is needed especially in terms of perceiving everything that is in the environment through the sensory tools that are owned (Sunaryo, 2004). However, the family's perception of cardiovascular disease emergencies in the family members who have the risk factors of cardiovascular disease is still unknown. So, the researchers are interested in examining how the families perceive emergency cardiovascular disease at home. The purpose of this study is to explain how the family experiences dealing with emergency heart disease at home.

\section{MATERIALS AND METHODS}

This study used a qualitative methodology with a case study approach. In this study, the researchers sought to elaborate on and explore extensively the family experiences in dealing with the emergence of cardiovascular disease at home. The data was collected using 2 participants who were family members who had experienced cardiovascular emergency cases and 1 participant who was a village nurse for the triangulation. The emergency cardiovascular disease referred to in this study was a heart attack that happened at home.

The data was collected from August to November 2018 in the PKM (Public of Health Center) of Jabon working area, Jombang. In-depth interview techniques were used in the participant information retrieval. The researchers tried to develop questions from the information obtained from the participants so then they experienced saturated data. The researcher conducted an observation and recording of all of the non-verbal characteristics during the data retrieval process.

The interview data was analyzed using Uwe Flick (Flick, 2018). The practical steps of analyzing and representing the interview data were performed. The data analysis began with (1) reducing the data to locate and examine the phenomena of interest. In this phase, the interviews were transcribed and then the data was read and reread. The next phase was (2) reorganizing, classifying and categorizing the data, in which the researchers generated assertions about the topics by reassembling and reorganizing the data, codes, categories and stories. The last phase was (3) interpreting and writing up the findings. In this phase, the researcher considered the assertions and
Table 1: Participant Information

\begin{tabular}{ccccc}
\hline Participants & Age & Gender & Occupation & Education \\
\hline Participant 1 & 45 & Female & Housewife & High \\
& Years & & & School \\
Participant2 & 77 & Male & Retired civil & High \\
& Years & & servant & School \\
Participant 3 & 35 & Female & Nurse & Diploma \\
& Years & & & Nursing \\
\hline
\end{tabular}

propositions in light of the prior research and theory to develop arguments. The researchers developed stories that conveyed the main idea developed in the data analysis and furthermore, they presented the data excerpts and stories to the support assertions.

Ethical approval to conduct this study was granted by the Health Research Ethics Committee STIKES Pemkab Jombang ethical clearance number $0318070027 /$ KEPK/STIKES-PEMKAB/JBG/V/2018.

All of the participants were provided with a participant information sheet written in Bahasa Indonesia and they signed the consent form prior to participating in the study.

\section{RESULT}

The informants of the study were 3 people (informants 1 and 2 were the families of patients who experienced an emergency at home, and informant 3 was a nurse at the health center as triangulation. The characteristics of the informants in this study included their age, sex, occupation and recent education (Table 1).

\section{Knowledge}

In this study, the theme of knowledge became the first theme found. The participants said that they did not know about heart disease, along with the signs and symptoms.

P 1: "Previously I never knew if I had heart disease. Previously, I had never heard of diabetes and its prevention."

P 2: "Never knew... sudden chest pain and shortness of breath."

\section{Past Experience}

The theme of past experience becomes the second theme found. The absence of past experience makes the family confused when making decisions.

$P$ 1: "We have never experienced a heart attack before. Because now we know, so we looked after ourselves, especially food."

P 2: "Sudden, unprecedented. I called my child who then told me to be taken to the hospital. Now we are more careful at maintaining health."

\section{Value}

The third theme found is the theme of value. The values contained in the family make the family the main support system in the face of emergency cardiovascular disease. 
P 1: "I don't know anything. As soon as my husband fell, I immediately called Mantri(Male Nurse) and the nearest neighbor."

P 2: "When an attack occurs, I am confused about what to do. I called my child. Incidentally my child is a doctor. I call Mantri (Male nurse), ask for help from neighbors and my child suggests entering the ICU."

\section{Belief}

The fourth theme found was belief. The family confidence in addressing health and illness influences the family attitude in decision making. Family belief is an internal factor in relation to behaving. Families have different beliefs about caring for their family members.

P 1: "The pain is due to cholesterol, and cigarettes. Every day I run out of 2 packs of cigarettes. Then 2 days before the attack, I thought Masuk angina (colds) and the complaint when belching was like being caught in the neck."

\section{"I surrender to God."}

P 2: "Actually, before getting sick, it was difficult to take care of her, especially regarding food and then the attack occurred."

"Give up and believe in the Creator and doctor."

\section{DISCUSSION}

This study raises the question regarding the family experience in dealing with emergency cardiovascular disease at home. There are 4 themes related to the family experience of dealing with emergency cardiovascular diseases at home and determining family decision making. Knowledge of diseases, disease processes, past experiences in dealing with similar diseases, values and beliefs were the themes found in this study. The success of treating emergency cardiovascular disease is determined by the closest bystander (Wissenberg et al., 2013). Often, the emergency events of cardiovascular disease at home are not handled properly. This can lead to death from a heart attack(Myerburg \& Junttila, 2012; Sayre et al., 2008). The family experience in dealing with emergency cardiovascular diseases is reflected in their attitudes, behaviors and family decision-making in dealing with these events.

A person's attitude and behavior in relation to making decisions is strongly influenced by many factors (Suharyat, 2009). Knowledge is one of the factors that can influence attitudes and behavior. Knowledge can influence the attitudes and behavior in decision making(Melani, 2013; Suharyat, 2009). This means that high knowledge can result in positive attitudes and behaviors when making decisions. Likewise with the participants, the family has no knowledge in the context of the emergency of cardiovascular disease. Therefore, decision making is diverse. One participant said that he had to contact his son in decision making. One said that the patients were only treated like colds.

For sudden events, the absence of prior experience can also influence the family when making decisions. Heart disease is known to be very slow in society. Inaccuracies in pre-hospital treatment often lead to death and disability (Sayre et al., 2008). The incidence of a heart attack tends to be sudden, which means that the communities do not understand and do not have prior experience in overcoming it.

Values in family are the main pods that make the family the main support system in all things(Milne et al., 2009). The values and norms that exist within the family and society are a consideration point for the families (Lestari, 2012). The values contained in the family become the basis of their behavior and attitude(McLaughlin \& Braun, 1998). The values held by the families make the person have a sense of responsibility, trust or even to depend on their family members(Ali \& SKM, 2010; Friedman et al., 2010). Thus, family values and norms make the family members feel mutually possessed, trusting and where they can depend on each other.

Belief in something can influence family perception(Smets, 2002). In addition, belief in a strong value is able to encourage the community in decision making(Ali \& SKM, 2010; Friedman et al., 2010; Smets, 2002; Walsh, 2003). This is in accordance with the results of the study which stated that they were submissive to the provisions of the One. In addition, families have known that the causes of heart disease are cigarettes and food but the value in society about smoking and food affects people's attitudes and behavior in terms of consuming food and cigarettes. Cigarettes are considered a means of social life.

\section{CONCLUSION}

Emergency cardiovascular disease occurs suddenly and is unknown to family members. The family experience in dealing with emergency cardiovascular disease at home determines the attitude and decision making in the family. The experience includes the family knowledge of handling emergency cases, past experience and their values and beliefs. Family experience illustrates how families behave when facing health hazards. Thus the family behavior can be analyzed when conducting pre-hospital treatment.

\section{REFERENCES}

Adiatmaja, I. (2004). Analisis Faktor Risiko yang Berpengaruh terhadap Skor Kardiovaskular Jakarta dan Skor Framingham pada Pekerja PT XJakarta (Tesis). Jakarta: Universitas Indonesia.

Ali, H. Z., \& SKM, M. B. A. (2010). Pengantar keperawatan keluarga. EGC.

BALITBANGKES. (2014). Hasil RISKESDAS. Jakarta.

Dalen, J. E., Alpert, J. S., Goldberg, R. J., \& Weinstein, R. S. (2014). The epidemic of the 20th century: coronary heart disease. The American Journal of Medicine, 127(9), 807-812. 
Delima, D., Mihardja, L., \& Siswoyo, H. (2009). Prevalensi dan faktor determinan penyakit jantung di Indonesia. Indonesian Bulletin of Health Research, 37(3).

Flick, U. (2018). Designing qualitative research. Sage.

Friedman, M., Bowden, V., \& Jones, E. (2010). Buku Ajar Keperawatan Keluarga Riset, Teori \& Praktik (5th ed.; E. Tiar, Ed.). Jakarta: EGC.

Lestari, S. (2012). Psikologi keluarga: Penanaman nilai dan penanganan konflik dalam keluarga. Sri Lestari.

McLaughlin, L. A., \& Braun, K. L. (1998). Asian and Pacific Islander cultural values: considerations for health care decision making. Health \& Social Work, 23(2), 116-126.

Melani, A. (2013). Studi kualitatif pengambilan keputusan dalam keluarga terkait dengan komplikasi perinatal di Kabupaten Cianjur Jawa Barat. Jurnal Kedokteran Brawijaya, 24(3).

Milne, B. J., Caspi, A., Harrington, H., Poulton, R., Rutter, M., \& Moffitt, T. E. (2009). Predictive value of family history on severity of illness: the case for depression, anxiety, alcohol dependence, and drug dependence. Archives of General Psychiatry, 66(7), 738-747.

Myerburg, R. J., \& Junttila, M. J. (2012). Sudden cardiac death caused by coronary heart disease. Circulation, 125(8), 1043-1052.

Sayre, M. R., Berg, R. A., Cave, D. M., Page, R. L., Potts, J., \& White, R. D. (2008). Hands-only (compression-only) cardiopulmonary resuscitation: a call to action for bystander response to adults who experience out-of-hospital sudden cardiac arrest: a science advisory for the public from the American Heart Association Emergency Cardiovascular Care Committee. Circulation, 117(16), 2162-2167.

Smets, P. (2002). Decision making in a context where uncertainty is represented by belief functions. In Belief functions in business decisions (pp. 17-61). Springer.
Suastika, K. (2016). Improving Management of Endocrine Disorder in Clinical Practice. In K. Suastika, A. Budhiarta, W. Gotera, M. Saraswati, \& I. Dwipayana (Eds.), Bali endokrin update (BEU $X I V)$. Denpasar: Percetakan Bali.

Suharyat, Y. (2009). Hubungan antara sikap, minat dan perilaku manusia. Jurnal Region, 1(3), 1-19.

Sunaryo. (2004). Psikologi untuk Keperawatan. Jakarta: EGC.

Voss, R., Cullen, P., Schulte, H., \& Assmann, G. (2002). Prediction of risk of coronary events in middleaged men in the Prospective Cardiovascular Münster Study (PROCAM) using neural networks. International Journal of Epidemiology, 31(6), 1253-1262.

Walsh, F. (2003). Family resilience: A framework for clinical practice. Family Process, 42(1), 1-18.

WHO. (2016). Cardiovascular disease.

Wissenberg, M., Lippert, F. K., Folke, F., Weeke, P., Hansen, C. M., Christensen, E. F., ... Olesen, J. B. (2013). Association of national initiatives to improve cardiac arrest management with rates of bystander intervention and patient survival after out-of-hospital cardiac arrest. Jama, 310(13), 1377-1384.

Wyatt, S. B., Akylbekova, E. L., Wofford, M. R., Coady, S. A., Walker, E. R., Andrew, M. E., ... Jones, D. W. (2008). Prevalence, awareness, treatment, and control of hypertension in the Jackson Heart Study. Hypertension, 51(3), 650-656. 